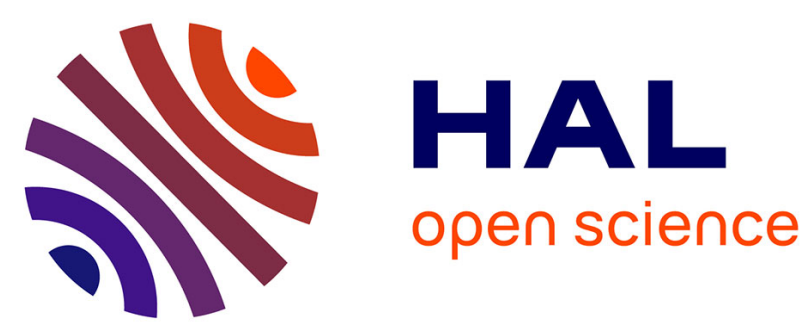

\title{
COMPARATIVE STUDY OF THE OPTICAL PROPERTIES OF SILVER CLUSTERS AND SILVER CONTINUOUS OVERLAYERS ON ALUMINIUM SUBSTRATE BY DIFFERENTIAL REFLECTOMETRY
}

Yves Borensztein, T. López-Ríos, G. Vuye

\section{To cite this version:}

Yves Borensztein, T. López-Ríos, G. Vuye. COMPARATIVE STUDY OF THE OPTICAL PROPERTIES OF SILVER CLUSTERS AND SILVER CONTINUOUS OVERLAYERS ON ALUMINIUM SUBSTRATE BY DIFFERENTIAL REFLECTOMETRY. Journal de Physique Colloques, 1983, 44 (C10), pp.C10-475-C10-478. 10.1051/jphyscol:19831095 。 jpa-00223553

HAL Id: jpa-00223553 https://hal.science/jpa-00223553

Submitted on 1 Jan 1983

HAL is a multi-disciplinary open access archive for the deposit and dissemination of scientific research documents, whether they are published or not. The documents may come from teaching and research institutions in France or abroad, or from public or private research centers.
L'archive ouverte pluridisciplinaire HAL, est destinée au dépôt et à la diffusion de documents scientifiques de niveau recherche, publiés ou non, émanant des établissements d'enseignement et de recherche français ou étrangers, des laboratoires publics ou privés. 


\title{
COMPARATIVE STUDY OF THE OPTICAL PROPERTIES OF SILVER CLUSTERS AND SILVER CONTINUOUS OVERLAYERS ON ALUMINIUM SUBSTRATE BY DIFFERENTIAL REFLECTOMETRY
}

\author{
Y. Borensztein, T. López-Ríos and G. Vuye \\ Laboratoire d'optique des Solides, ERA CNRS 462, Université Pierre et Marie \\ Curie, 4, Place Jussieu, 75230 Paris Cedex 05, France
}

\begin{abstract}
Résumé - Les propriétés optiques de couches minces d'argent déposées sur aluminium propre et oxydé sont étudiées. Sur l'aluminium propre, l'argent croit monocouche par monocouche. Le bord d'absorption est dëplacé vers les grandes énergies pour les épaisseurs les plús faibles, et atteint la position du métal massif pour un recouvrement de plusieurs monocouches. Sur l'aluminium oxyđé les atomes d'argent se regroupent en amas, et on étudie l'évolution au bord a'absorption. De plus, on observe deux absorptions optiques, qui sont interprétées comme étant des résonances electromagnétiques causées par des oscillations collectives d'électrons dans les amas.
\end{abstract}

\begin{abstract}
The optical properties of thin films of silver deposited on clean and oxidized aluminium are studied. On clean aluminium, silver is growing monolayer after monolayer. The absorption edge is shifted to greater energies for the lowest thicknesses, and reaches the bulk position for coverage of several monolayers. On oxidized aluminium silver atoms form clusters, and we follow the gradual change of the absorption edge. Moreover, two optical absorption bands are observed, and interpreted as electro-magnetic resonances caused by collective electronic oscillations in the clusters.
\end{abstract}

\section{INTRODUCTION}

We present here some preliminary results about the optical properties of thin films of silver deposited on either clean or oxidized aluminium. Two main points are under consideration. On the one hand we study the gradual apparition of bulk silver electronic properties during the growth of continuous films or of clusters. On the other hand, two absorption peaks are observed in the case of silver on alumina, which are related to the collective oscillations of the conduction electrons in the silver clusters.

\section{EXPERIMENTAL ASPECTS}

The samples are prepared in situ by evaporation on fused silica substrate maintained at room temperature. The pressure is in the $10^{-9}$ porr range during Al evaporation, and below 4,10-10 Torr during Ag evaporation. The thickness of the metal deposits is controlled with a $5 \mathrm{MHz}$ quartz microbalance calibrated by thickness measurements using grazing incidence x-ray interferometry, the uncertainty being below $10 \%$

The optical measurements are performed in situ with a differential reflectometer : a monochromatic optical beam is focussed alternatively on the two halves of a sample, one of them being the clean or oxidized Al surface, the other one the same surface covered by the Ag atoms. That leads to the quantity $\Delta R / R=2\left(R-R_{0}\right) /\left(R+R_{0}\right)$, where $R_{0}$ and $R$ are the reflectivities of the bare and 
covered surfaces respectively ; the sensitivity on $\Delta R / R$ is about $10^{-4}$ in the $1.5-3.5 \mathrm{eV}$ range and $3.10^{-4}$ in the $3.5-5.2 \mathrm{eV}$.

\section{SILVER OVERLAYERS UPON CLEAN ALUMINIUM}

Our aluminium films (300 to $500 \stackrel{\circ}{\mathrm{A}}$ thick) are formed of crystallites of about $500 \stackrel{\circ}{\mathrm{A}}$, most of them having a preferred orientation [111] nearly perpendicular to the substrate surface (1). Silver overlayers present a Van der Merwe mode of growth, as controlled by Auger spectroscopy, and therefore form continuouslayers having mainly a (111) structure (2).

Figures 1 and 2 show the $\Delta R / R$ spectra for increasing $A g$ thicknesses, expressed in (111) monolayer (ML), one ML corresponding to a mass thickness of $2.35 \mathrm{~A}$.

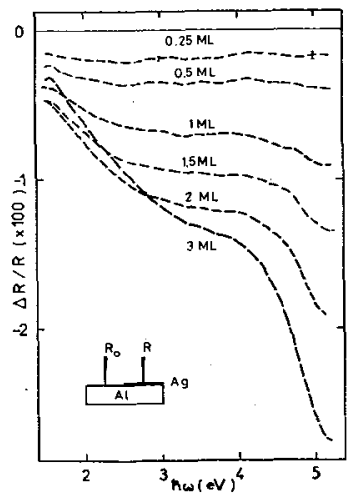

Figure 1.

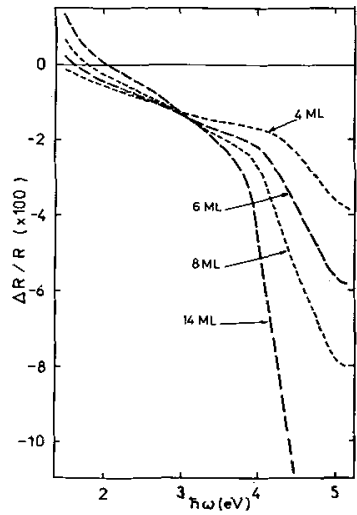

Figure 2.

Differential reflectivity spectra at normal incidence for various thicknesses expressed in monolayers (ML) of the Ag superficial layers, deposited on a Al film $300 \AA$ thick.

Below one monolayer, a constant optical absorption over the whole spectral range is observed, which is probably due to the modification of the Al conduction electrons scattering at the surface, induced by the presence of Ag atoms (3). The Ag absorption edge becomes apparent for thicknesses of the order of the monolayex, and is shifting towards lower energies with increasing thickness. For the thicker layer (14 ML) the optical properties of bulk Ag are obtained, and the interband absorption onset is determined at about $3.90 \mathrm{eV}$, in conformity with previous works $(4,5)$. The shift towards higher energy with regard to the Ag bulk absorption edge for thinner layers is indicating that the a band in the one or two monolayers case should lie at lower energies below $\mathrm{E}_{\mathrm{F}}$, in agreement with previous results for Ag layers deposited on $\mathrm{Si}(111)$ (6). In fact, the Ag absorption edge is composed of two different contributions (7), one from transitions from the top of the d-band to the conduction band at the Fermi level, the other, very sensitive to the Ag structure, from transitions between two conduction bands. More carefui investigations are needed to follow the gradual change of each contribution to the absorption edge. 
Under exposure to a few Langmuirs (L) of oxygen, intermediate oxidation states occur on the different crystallographic surfaces of Al; they are followed by the formation of amorphous alumina $\left(\mathrm{Al}_{2} \mathrm{O}_{3}\right)$ at high exposure $(8,9)$. The Al film was exposed to $10^{-4}$ Torr pressure of oxygen during several minutes, i.e. to several thousands Langmuirs. Pressure was then removed in the $10^{-9}$ Torr range within a few minutes. Auger electron spectroscopy showed an important $54 \mathrm{eV}$ peak, characteristic of oxidized $\mathrm{Al}$, while the $68 \mathrm{eV}$ Al metal $\mathrm{L}_{23} \mathrm{VV}$ transition had almost disappeared.

As it can be seen on figure 3 where electron transmission micrographs are presented for three mass thicknesses : $2.5 \AA, 12 \AA$, and $20 \AA$ of $\mathrm{Ag}$ deposited on oxidized $\mathrm{Al}$, $\mathrm{Ag}$ atoms gather to form clusters. In the $2.5 \AA$ film, the clusters are gathered at particular locations which may be some cracks in the superficial alumina film. For larger thicknesses, the cluster distribution seems more uniform. In the two thinnest films, the clusters appear to be spherical, with dimensions of about $20-50 \mathrm{~A}$; in the thickest film, the clusters are

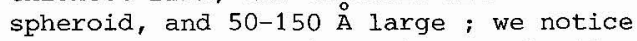
in this film some micro-clusters besides the larger ones.

Figures 4 and 5 show the differential reflectivity spectra for Ag layers on oxidized Al, the amount of silver being expressed in equivalent mass thickness. The Ag absorption edge appears already for the thinnest layer investigated, $0.25 \AA$ thick; it is shifted towards higher energy. We recall that, for a continuous Ag film on clean Al, the absorption edge becomes apparent at only one monolayer, $2.35 \AA$ thick (fig. 1). For the $6 \mathrm{~A}$ thick film, the absorption edge almost reaches the bulk position, which means that clusters of some tens $\AA$ display nearly bulk electronic features, so does a continuous silver film of some tens $\AA$, as it was clear from fig. 2 .

Otherwise, the $\Delta R / R$ spectra in figs. 4 and 5 display important absorption peaks. For the thinnest films, from $0.25 \AA$ to $6 \AA$, only one peak is observed, shifting from $3.50 \mathrm{eV}$ to $3.30 \mathrm{eV}$ with increasing thickness. This absorption is intexpreted as an electromagnetic resonance caused by collective oscillation of the conduction electrons in the spherical Ag clusters, which can be modelized by means of an effective medium theory (10). Such a model leads to a resonance precisely located at $3.50 \mathrm{ev}$.
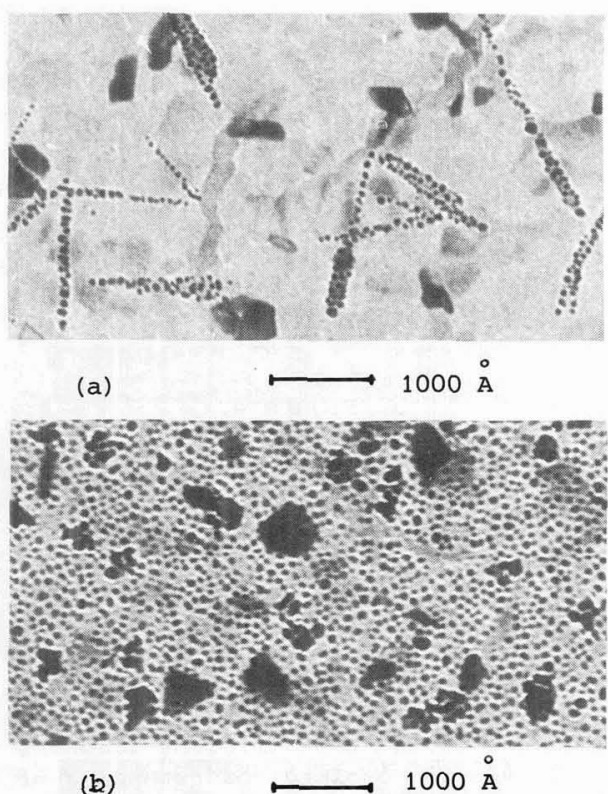

(b)

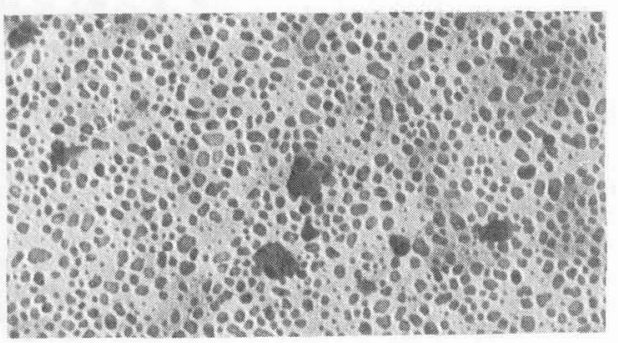

(c)

$1000 \AA$

Figure 3. Electron transmission micrographs of Ag films deposited on a $200 \AA$ thick Al film. The Ag films thicknesses are :

(a) $2.5 \AA, \quad$ (b) $12 \AA$, (c) $20 \AA$ 


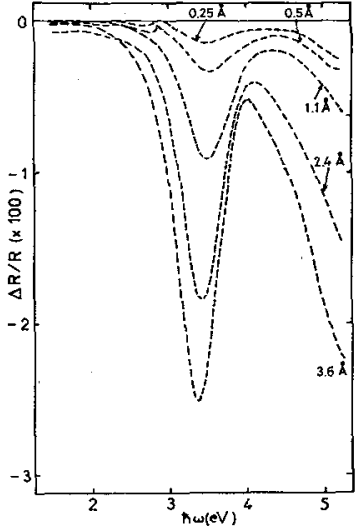

Figure 4.

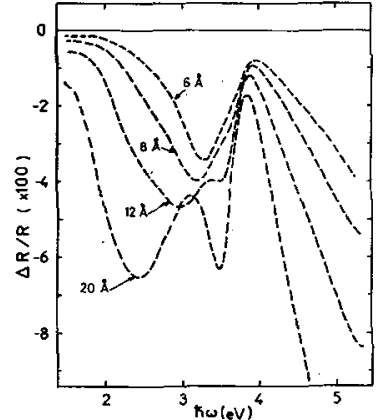

Figure 5.

Differential reflectivity spectra at normal incidence for various thicknesses expressed in mass thickness of the Ag superficial layers, deposited on a Al film $485 \AA$ thick.

A possible explanation of the shift is the interaction between the clusters and the substrate (11). For the thickest films, two peaks are observed, one at about $3.5 \mathrm{eV}$, the other one shifting towards lower energies. These two absorptions are related to the two different resonant modes in silver spheroids or cluster strings $(10,12)$. A complete understanding of the gradual modifications of these absorption peaks with increasing thickness should require a thorougher investigation. Experiments by F. Miserey et al (13) on identical systems show that the two peaks go on shifting towards low energies with increasing Ag film thickness, until they disappear above $400 \AA$. It must be pointed out that the low energy peak is closely related to Surface Enhancement Raman Scattering. (S.E.R.S.) (11), and actually a SERS signal with oxygen exposure could be obtained on our sample supporting the thicker silver film (20 ̊).

\section{REFERENCES}

1. ChaUvineau J.P., Thèse d'Etat Paris (1968).

2. LÓPEZ-RÍos T. and VUYE G., J. Phys. E 15 (1982) 455.

3. PARISET C. and CHAUVINEAU J.P., Surface Sci. 78 (1978) 478.

4. EHRENREICH H. and FEIIIPP H.R., PhYS. Rev. $12 \overline{8}$ (1962) 1622.

5. DUJARDIN M.M. and SHEYE M.L., J. Phys. Chem. Solids 32 (1971) 2033.

6. DERRIEN J., LE IAY G. and SALVAN F., J. Physique Lettres 39 (1978) L287.

7. WINSEMIUS P., Thesis Leiden University (1973).

8. MICHEL R., GASTALDI J., ALLASIA C., JOURDAN C. and DERRIEN J., Surface Sci. 95 (1980) 309.

9. KOBAYASHI K.L.I., SHIRAKI Y. and KATAYAMA Y., Surface Sci. 77 (1978) 449.

10. COHEN R.W., CODY G.D., COUTTS M.D. and ABELES B., Phys. Rev. B8 (1973) 3689.

11. RUPPIN R., Surface Sci. 127 (1983) 108.

12. BLATCHFORD C.G., CAMPBELI J.R. and CREIGHTON J.A., Surface SCi. 120 (1982) 435. 13. MISEREY F. and SEPTIER A., To be published in C.R. Acad. Sci. Paris, Série II.

ACKNOWLEDGEMENTS - We are grateful to Dr. F. MISEREY and Prof. A. SEPTIER for supplying a copy of ref. (13) and for helpful discussions. We thank also S, FISSON for the electron micrographs and Dr. M.L. THEYE for advice and help. 